\section{Infant mortality in three population-based cohorts in Southern Brazil: trends and differentials}

\author{
Mortalidade infantil em três coortes de base \\ populacional no Sul do Brasil: \\ tendências e diferenciais
}

\author{
1 Programa de Pós-graduação \\ em Epidemiologia, \\ Universidade Federal de \\ Pelotas, Pelotas, Brasil. \\ 2 Faculdade de Medicina \\ Universidade Católica de \\ Pelotas, Pelotas, Brasil. \\ 3 Programa de Pós-graduação \\ em Saúde e Comportamento, \\ Universidade Católica de \\ Pelotas, Pelotas, Brasil. \\ Correspondence \\ I. S. Santos \\ Programa de Pós-Graduação \\ em Epidemiologia, \\ Universidade Federal de \\ Pelotas. \\ Rua Marechal Deodoro 1160, \\ 3 o andar, Pelotas, RS \\ 96020-220, Brasil. \\ inasantos@uol.com.br
}

\section{Abstract}

We studied time trends in infant mortality and associated factors between three cohort studies carried out in Pelotas, Rio Grande do Sul State, Brazil, in 1982, 1993, and 2004. All hospital births and deaths were determined by means of regular visits to hospitals, registrar's offices, and cemeteries. This data was used to calculate neonatal, post-neonatal, and infant mortality rates per thousand live births. Rates were also calculated according to cause of death, sex, birth weight, gestational age, and family income. The infant mortality rate fell from 36.4 per 1,000 live births in 1982 to 21.1 in 1993 and 19.4 in 2004. Major causes of infant mortality in 2004 were perinatal causes and respiratory infections. Mortality among low birth weight children from poor families fell 16\% between 1993 and 2004; however, this rate increased by more than $100 \%$ among high-income families due to the increase in the number of preterm deliveries in this group. The stabilization of infant mortality in the last decade is likely to be due to excess medical interventions relating to pregnancies and delivery care.

Infant Mortality; Low Birth Weight Infant; Premature Birth; Income; Cohort Studies

\author{
Iná S. Santos 1 \\ Ana M. B. Menezes 1 \\ Denise M. Mota ${ }^{1}$ \\ Elaine P. Albernaz 2 \\ Aluísio J. D. Barros 1 \\ Alicia Matijasevich 1 \\ Fernando C. Barros ${ }^{3}$ \\ Cesar G. Victora 1
}

\section{Introduction}

Estimated infant mortality in Brazil fell from 39.5 per thousand in 1994 to 26.6 in 2004 . Between 2000 and 2003, mortality decreased in all of the country's 26 states. This reduction was greater in the Northeast Region (which saw a 13.5\% decrease) and less marked in the South (7.3\%) ${ }^{1}$. The major factor underlying such a reduction was a decrease in post-neonatal mortality; as a consequence, neonatal deaths now account for the greater proportion of infant deaths in Brazil.

The major causes of death in the first year of life in Brazil also changed in the last two decades. Infectious diseases gave way to perinatal causes as the major cause of death, the latter now representing over $50 \%$ of all infant deaths. These deaths are related to problems during pregnancy, delivery, and in the first week of life 1 . Interventions implemented during this period have also contributed to the decrease in infant mortality. These include women's health and specific child health programs, oral rehydration therapy, incentives to breastfeeding, increases in immunizations, and a decrease in fecundity 2 .

In spite of this decline, infant mortality continues to be a major Public Health concern - in 2004 alone, 90 thousand children under the age of one year died in Brazil, and most of these deaths were from preventable causes 3 .

The routine data currently available in Brazil do not allow for the study of mortality according 
to socioeconomic factors and birth weight, which requires specific surveys with primary data collection. The three population-based birth cohort studies carried out in Pelotas, Southern Brazil, in 1982, 1993, and 20044 included all children born in the city's hospitals in these years, thus creating a system for monitoring infant deaths. The aim of the present article is to explore the causes for and time trends in infant mortality across these two decades, and to evaluate the role of family income and birth weight as determinants of this important health indicator.

\section{Methods}

In 1982, 1993, and 2004, we studied all births that took place in hospitals in the city of Pelotas, Southern Brazil, from which three infant cohorts therefore originated. Detailed descriptions of the methods employed in these studies are available elsewhere 4 . The methods used in the infant mortality sub-studies conducted during the 1982 and 1993 cohorts have also been described 5,6. In the 2004, cohort, we monitored all infant deaths that took place between 1 January 2004 and 31 December 2005, when the last child born in 2004 reached one year of age.

In the three cohorts, mortality analyses included deaths that took place in the early neonatal (first seven days of life), late neonatal ( $8^{\text {th }}-28^{\text {th }}$ day), and post-neonatal (28th-364th day) periods. Deaths were monitored by means of regular visits to the city's five hospitals, where intensive care units, maternity wards, pediatric wards, and emergency rooms were visited. To monitor deaths that took place outside of hospitals, we also visited the city's registrar's offices, cemeteries, and the Regional Health Coordination. The mortality database (Mortality Information System - SIM) for the State of Rio Grande do Sul was also screened to search for deaths that occurred outside Pelotas.

Information on underlying causes of death was collected by interviewing the child's pediatrician. In the case of hospitalized children, we carried out a systematic review of the child's hospital chart, collecting information on the reason for admission, disease history and evolution, complementary tests, treatment, and diagnosis. When necessary, the information included in the perinatal questionnaire administered to the mother soon after childbirth was also used.

In case a child was not discharged from the hospital after delivery, the study team would follow the evolution of the case on a daily basis. For deaths that occurred between seven and 364 days of life, we carried out a home interview with the child's mother, investigating the clinical history and background of the illness. For this interview, we adapted questionnaires used in the inter-American investigation of mortality in childhood 7, adapted to local settings. For deaths that took place outside the hospital or in other cities, information was obtained from death certificates and complemented by household interviews. Losses and refusals at the follow-up stage amounted to $9.7 \%$. In each cohort, two independent pediatricians were responsible for determining the underlying cause of death by carefully reviewing available information. In the case of a disagreement, a third pediatrician was invited to discuss the case in order for a consensus to be reached.

Death certificates were coded according to the International Classification of Diseases 8,9.

Independent variables used in this analysis included sex, family income as a multiple of the monthly minimum wage (MW), birth weight in grams, and gestational age. Family income was calculated as the sum of the incomes of each household member in the month preceding birth. This variable was categorized into five groups: $\leq 1.0,1.1-3.0,3.1-6.0,6.1-10.0$ and > 10.0 MW. In the three cohorts, birth weight was measured and recorded by the hospital's nurses immediately after birth, using pediatric scales calibrated by the study team. In 1982, the gestational age was calculated based on the date of last menstrual period, and children with birth weight incompatible with normal standards for that age 10,11 were considered to be of unknown gestational age. In 1993 and 2004, the Dubowitz score was also employed to evaluate the maturity of the newborn, and, in each case, the most plausible estimate considering birth weight, length, and head perimeter was chosen 12 . Births before the 37 th week of pregnancy were classified as preterm. Newborns weighing under $2,500 \mathrm{~g}$ were classified as low birth weight. The presence of an intrauterine growth restriction was determined based on the Williams curve 13. We classified as "small for gestational age" (SGA) children below percentile 10 of weight for gestational age and sex; the remaining children were classified as "appropriate for gestational age" (AGA).

The infant mortality rate, with its neonatal and post-neonatal components, was compared to those of 1982 and 1993. Births for which gestational age was unknown were excluded only from specific analyses by gestational age. The association between independent variables and mortality rates was tested using the chi-squared test. Whenever possible, the linear trend test was used. In some analyses, the relative risks of certain outcomes were analyzed, comparing differ- 
ent family income and birth weight groups. The interaction between birth weight and family income was tested in all three cohorts by analyzing the effect of birth weight on mortality stratified according to family income.

All analyses were carried out using the Stata statistical package (Stata Corp., Colege Station, USA).

The study protocol was approved by the Medical Research Ethics Committee of the Federal University of Pelotas. In 1982 and 1993, verbal consent was obtained from all mothers participating in the study. In 2004, in addition, written consent was also requested.

\section{Results}

The number of live births in 1982, 1993, and 2004 was $5,914,5,249$, and 4,231 , respectively. In the 2004 cohort, 82 children died before their first birthday. The corresponding number of deaths in 1993 and 1982 was 111 and 215, respectively (Table 1). The infant mortality rate fell from 36.4 per thousand live births in 1982 to 21.1 in 1993 and 19.4 in 2004 . This represented a $42 \%$ reduction between the first two cohorts and only an $8 \%$ reduction between the latter two. The reduction in the first period was due mainly to a decrease in post-neonatal deaths, which fell by $57 \%$. In the 1993-2004 period, post-neonatal rates remained stable at about 7 per 1,000 live births, whereas there was a slight reduction in neonatal mortality, from 14.3 to 12.3 per 1,000 live births.
The under-reporting rate for infant deaths, which was $24 \%$ in 1982 and had fallen to $5.4 \%$ in 1993, was null in 2004. For some of the causes of death (Table 2), the decreasing trend between 1982 and 1993 was maintained in 1993-2004. There was a slight decline in mortality due to perinatal causes $(p=0.2$ ), and a marked reduction in deaths due to diarrhea - a single child died of diarrhea in 2004, compared with 25 children in 1982 (a 95\% reduction in the mortality rate). Despite the decreasing trend, perinatal causes were still the most frequent in 2004, accounting for roughly one-half of all infant deaths.

Deaths due to congenital malformations, which had remained stable throughout the first decade, decreased by $60 \%$ (from 4.8 per 1,000 in 1993 to 1.9 in 2004), accounting for $10 \%$ of all infant deaths in 2004. The opposite trend was seen with deaths due to infectious and ill-defined causes. Although numbers were small, mortality rates for respiratory infections, other infections, and ill-defined causes were 2.4, six, and three times higher in 2004 than in 1993.

Table 3 shows that in all three cohorts, infant mortality was greater among boys. This difference is due to the neonatal component, given that post-neonatal mortality was very similar for both sexes. There was a slight reduction in the mortality rate for boys between 1993 and 2004 (from 25.2 to 21.4 per 1,$000 ; \mathrm{p}=0.4$ ); such a reduction was not observed among girls (16.9 and 17.2 per 1,$000 ; \mathrm{p}=0.9$ ).

Figure 1 shows neonatal and post-neonatal mortality, according to birth weight catego-

Table 1

Infant mortality in Pelotas, Southern Brazil, 1982, 1993, and 2004

\begin{tabular}{|c|c|c|c|}
\hline Indicators & 1982 & 1993 & 2004 \\
\hline Number of live births & 5,914 & 5,249 & 4,231 \\
\hline \multicolumn{4}{|l|}{ Neonatal deaths } \\
\hline Number & 119 & 75 & 52 \\
\hline Rate per 1,000 live births & 20.1 & 14.3 & 12.3 \\
\hline$\%$ of infant deaths & 55 & 68 & 63 \\
\hline \multicolumn{4}{|l|}{ Post-neonatal deaths } \\
\hline Number & 96 & 36 & 30 \\
\hline Rate per 1,000 live births & 16.2 & 6.9 & 7.1 \\
\hline$\%$ of infant deaths & 45 & 32 & 37 \\
\hline \multicolumn{4}{|l|}{ Infant deaths } \\
\hline Number & 215 & 111 & 82 \\
\hline Rate per 1,000 live births & 36.4 & 21.1 & 19.4 \\
\hline$\%$ of infant deaths & 100 & 100 & 100 \\
\hline
\end{tabular}


Number of deaths and cause-specific infant mortality rates in Pelotas, Southern Brazil, 1982, 1993, and 2004.

\begin{tabular}{|c|c|c|c|c|c|c|c|}
\hline \multirow[t]{5}{*}{ Causes } & \multicolumn{6}{|c|}{ Infant mortality } & \multirow{5}{*}{$p$ * } \\
\hline & 1982 & 1993 & 2004 & 1982 & 1993 & 2004 & \\
\hline & n (\%) & n (\%) & n (\%) & Rate per & Rate per & Rate per & \\
\hline & & & & 1,000 live & 1,000 live & 1,000 live & \\
\hline & & & & births & births & births & \\
\hline Perinatal & $92(43)$ & $57(51)$ & $41(50)$ & 15.4 & 11.1 & 9.7 & 0.2 \\
\hline Malformations & $27(13)$ & $25(23)$ & $8(10)$ & 4.5 & 4.8 & 1.9 & 0.9 \\
\hline Diarrhea & $25(12)$ & $9(8)$ & $1(1)$ & 4.2 & 1.7 & 0.2 & 0.005 \\
\hline Respiratory infections & $25(12)$ & $7(6)$ & $13(16)$ & 4.2 & 1.3 & 3.1 & 0.6 \\
\hline Other infections & $18(8)$ & $1(1)$ & $5(6)$ & 3.0 & 0.2 & 1.2 & 0.2 \\
\hline Other causes & $4(2)$ & $5(5)$ & $0(0)$ & 0.7 & 1.0 & 0.0 & - \\
\hline III-defined & $24(11)$ & $7(6)$ & $14(17)$ & 4.0 & 1.1 & 3.3 & 0.3 \\
\hline Total & $215(100)$ & $111(100)$ & $82(100)$ & 36.0 & 21.2 & 19.4 & - \\
\hline
\end{tabular}

* $\chi^{2}$ linear trend test.

Infant mortality rates (per 1,000 live births) according to sex in Pelotas, Southern Brazil, 1982, 1993, and 2004.

\begin{tabular}{|c|c|c|c|c|c|c|c|c|c|c|c|c|}
\hline \multirow[t]{2}{*}{ Sex } & \multicolumn{3}{|c|}{ Neonatal } & \multicolumn{3}{|c|}{ Post-neonatal } & \multicolumn{3}{|c|}{ Infant } & \multicolumn{3}{|c|}{ Number of births } \\
\hline & 1982 & 1993 & 2004 & 1982 & 1993 & 2004 & 1982 & 1993 & 2004 & 1982 & 1993 & 2004 \\
\hline Male & 22.1 & 17.8 & 15.0 & 15.8 & 7.4 & 6.4 & 38.2 & 25.2 & 21.4 & 3,083 & 2,603 & 2,196 \\
\hline Female & 17.4 & 10.5 & 9.3 & 16.0 & 6.4 & 7.9 & 33.3 & 16.9 & 17.2 & 2,926 & 2,687 & 2,035 \\
\hline$p^{*}$ & 0.2 & 0.02 & 0.09 & 0.9 & 0.6 & 0.6 & 0.4 & 0.04 & 0.3 & - & - & - \\
\hline
\end{tabular}

${ }^{*} \chi^{2}$ test.

ries, for children born in 1982, 1993, and 2004. Mortality among children with adequate birth weight $(\geq 2,500 \mathrm{~g})$ was markedly lower than that of low-birth weight children $(<2,500 \mathrm{~g})$, and showed a decreasing trend in the period, in both neonatal $(p=0.08)$ and post-neonatal $(p=0.001)$ components. Among low-birth weight children, on the other hand, there was a decline in both rates between 1982 and 1993, but rates remained stable in 1993-2004. As a result of these trends, the relative risk of neonatal death for low-birth weight children increased from 25 in 1982 and 1993 to 31 in 2004. For the post-neonatal component, relative risk went from 4.5 in 1982 to 3.3 in 1993 and back to 4.2 in 2004. In the 1982 cohort, the mortality rate was 206 per 1,000 live births for low-birth weight children and 18 per 1,000 live births for children with adequate birth weight. The respective rates were 114 and 10 per thousand live births in 1993 and 116 and 8 per 1,000 live births in 2004 .
In 2004, the infant mortality rate for SGA children remained stable in relation to 1993 $(p=0.006)$ (Table 4). The drastic reduction in mortality observed in this group occurred during the first period, between 1982 and 1993. The mortality rate among term babies with adequate weight showed a slight increase in 2004, from 6 to 8 per $1,000(p=0.4)$ in the first year of life, due to increases in both components of this indicator. In the group of preterm babies AGA, neonatal mortality remained stable in relation to 1993 $(p=0.2)$. This occurred concomitantly with a marked reduction in post-neonatal mortality in this group (from 20 to 9 per 1,000 live births; $p<$ 0.001 ), which led to a decrease in the infant mortality rate during the period (from 78 to 68 per 1,000 live births; $\mathrm{p}=0.001$ ).

Figure 2 presents infant mortality according to five categories of family. With the exception of the intermediate income group (3.1-6 MW), reductions in mortality were observed across all 
Figure 1

Infant mortality and low birth weight in Pelotas, Rio Grande do Sul State, Southern Brazil.

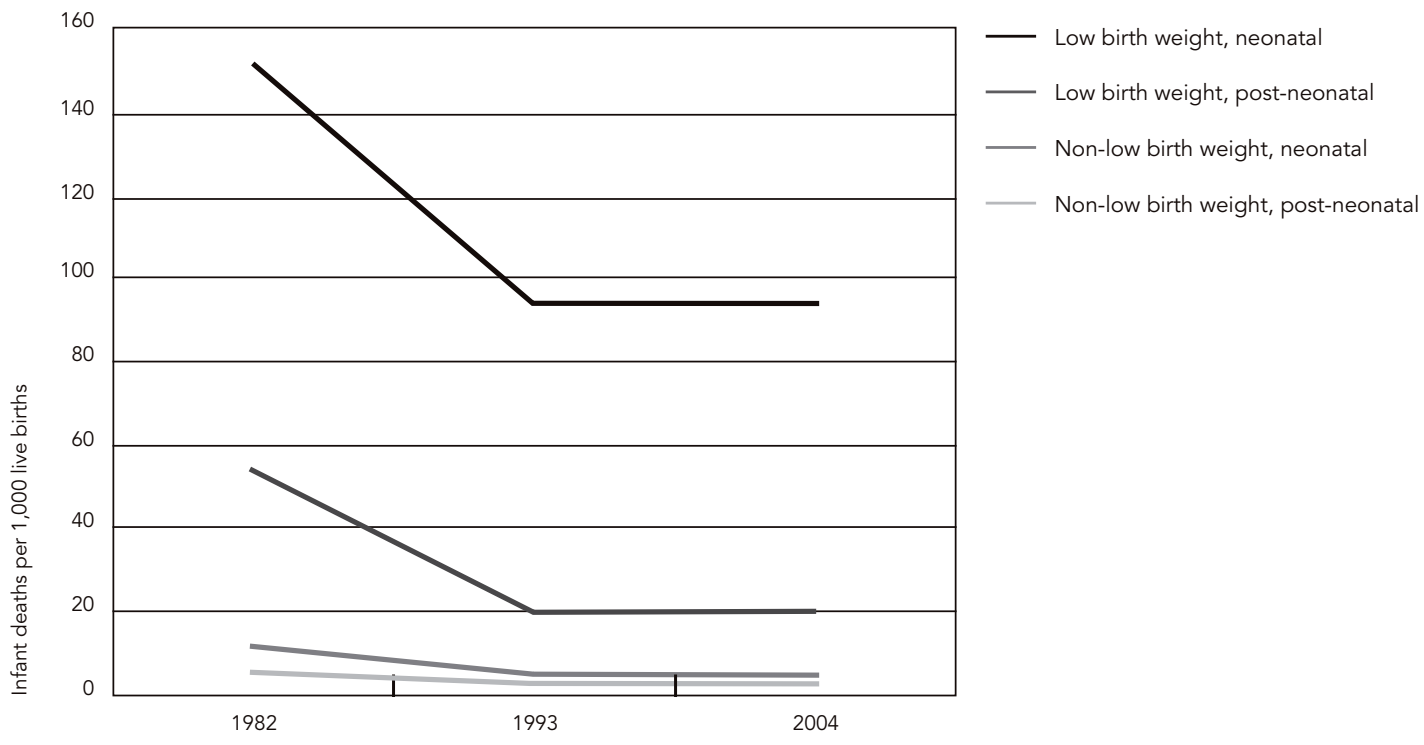

Table 4

Infant mortality rates (per 1,000 live births) according to intra-uterine growth restriction and gestational age in Pelotas, Southern Brazil 1992,1993 and 2004.

\begin{tabular}{|c|c|c|c|c|c|c|c|c|c|c|c|c|}
\hline \multirow{3}{*}{$\begin{array}{l}\text { Intra-uterine } \\
\text { growth } \\
\text { restriction } \\
\text { and } \\
\text { gestational } \\
\text { age }\end{array}$} & \multicolumn{9}{|c|}{ Mortality rates } & \multicolumn{3}{|c|}{ Deaths/Births } \\
\hline & \multirow[b]{2}{*}{1982} & \multirow{2}{*}{$\begin{array}{c}\text { Neonatal } \\
1993\end{array}$} & \multirow[b]{2}{*}{2004} & \multicolumn{3}{|c|}{ Post-neonatal } & \multirow[b]{2}{*}{1982} & \multirow{2}{*}{$\begin{array}{l}\text { Infant } \\
1993\end{array}$} & \multirow[b]{2}{*}{2004} & \multirow[b]{2}{*}{1982} & \multirow[b]{2}{*}{1993} & \multirow[b]{2}{*}{2004} \\
\hline & & & & 1982 & 1993 & 2004 & & & & & & \\
\hline SGA & 30 & 16 & 12 & 28 & 16 & 12 & 58 & 33 & 24 & $40 / 692$ & $16 / 487$ & $12 / 505$ \\
\hline \multicolumn{13}{|l|}{ AGA } \\
\hline Preterm & 93 & 58 & 59 & 62 & 20 & 9 & 155 & 78 & 68 & $40 / 258$ & $42 / 538$ & $38 / 558$ \\
\hline Term & 6 & 2 & 3 & 8 & 4 & 5 & 13 & 6 & 8 & $49 / 3,719$ & $26 / 4,139$ & $24 / 3,154$ \\
\hline$p^{*}$ & $<0.001$ & $<0.001$ & $<0.001$ & $<0.001$ & 0.001 & 0.6 & $<0.001$ & $<0.001$ & $<0.001$ & - & - & - \\
\hline
\end{tabular}

SGA: small for gestational age;

AGA: Apropriate for Gestational age.

* $\chi^{2}$ test. 


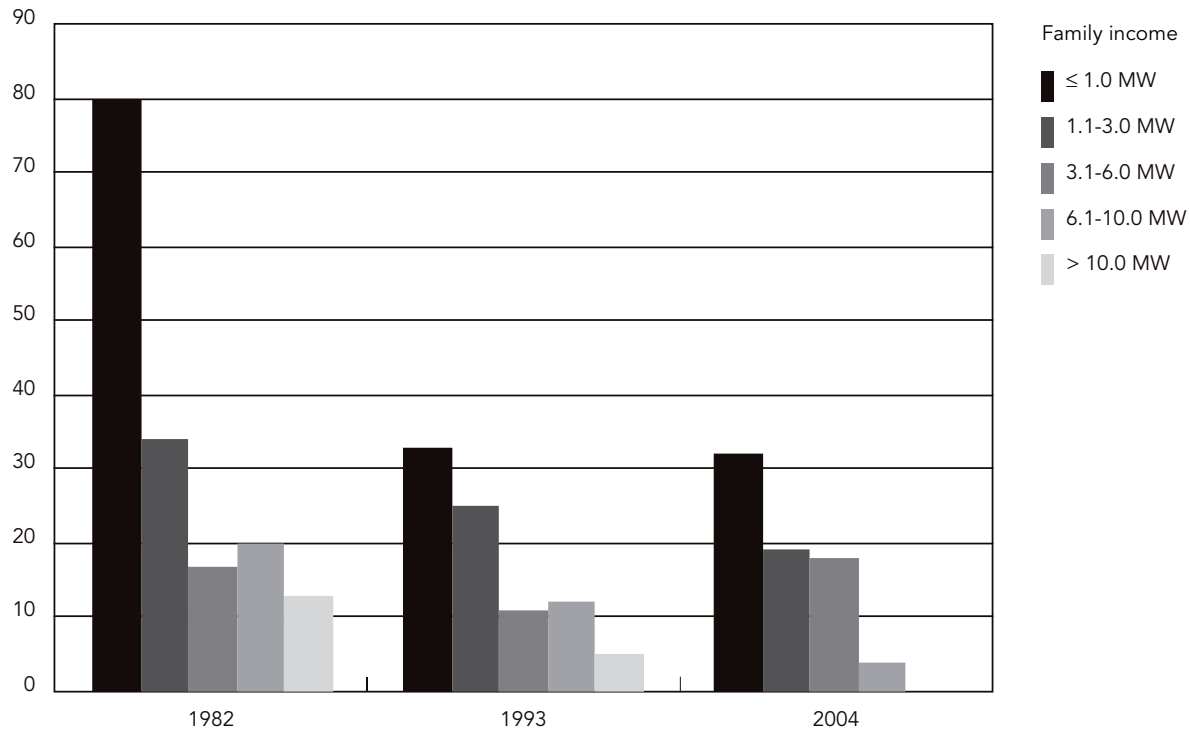

categories. This reduction, however, was not homogeneous, and was more pronounced among higher-income groups. In 2004, no deaths occurred among children in the highest income group (income $>10 \mathrm{MW}$ ). Among poorer children (up to $1 \mathrm{MW}$ ), the abrupt reduction seen between 1982 and 1993 did not reoccur in the second period, with the 2004 rate being practically the same as that of $1993(p=0.9)$, and - as in the previous cohort - higher than that of the other income categories.

Figure 3 shows infant mortality rates according to birth weight and family income. Among children born weighing 2,500g or more in richer families, the risk of death remained constant, at about 5 deaths per 1,000. On the other hand, among poor children in the same birth weight category, the greatest reduction in mortality occurred between the two first cohorts (from 25 to 12 per 1,000), with rates remaining stable between 1993 and 2004. The ratio between the mortality rates for poor and rich children with adequate birth weight decreased from five in 1982 to two in 1993 and 2004.

Figure 3 also shows that in the three cohorts, irrespective of income, the risk of death in the first year of life was always greater for children with low birth weight than for those with adequate birth weight. For children from both poor and wealthy families, there was an important reduction in mortality between 1982 and 1993, although reduction was more marked among children from wealthy families. Between 1993 and 2004, on the other hand, mortality fell slightly among those from poor families, but increased markedly among children from richer families.

In 1982, there was an interaction between birth weight and family income. Among low-birth weight children, the ratio between poor and rich was $1.5(220 / 148)$. This ratio was $5.0(25 / 5)$ among children with adequate birth weight. Such interaction was not seen in the subsequent cohorts: in 1993 , these ratios were $141 / 48$ and $12 / 5$, and in $2004,122 / 100$ and $10 / 5$, showing an important decrease in inequality during the period. A similar phenomenon was observed with regard to deaths among preterm babies, for which the mortality ratio fell from 3.4 in 1982 to 2.9 in 1993 and 1.5 in 2004 (data not shown).

\section{Discussion}

The principle limitations of the present study relate to the fact that family income was obtained directly from the mother, thus being subject to information bias, and to the lack of necropsy data 


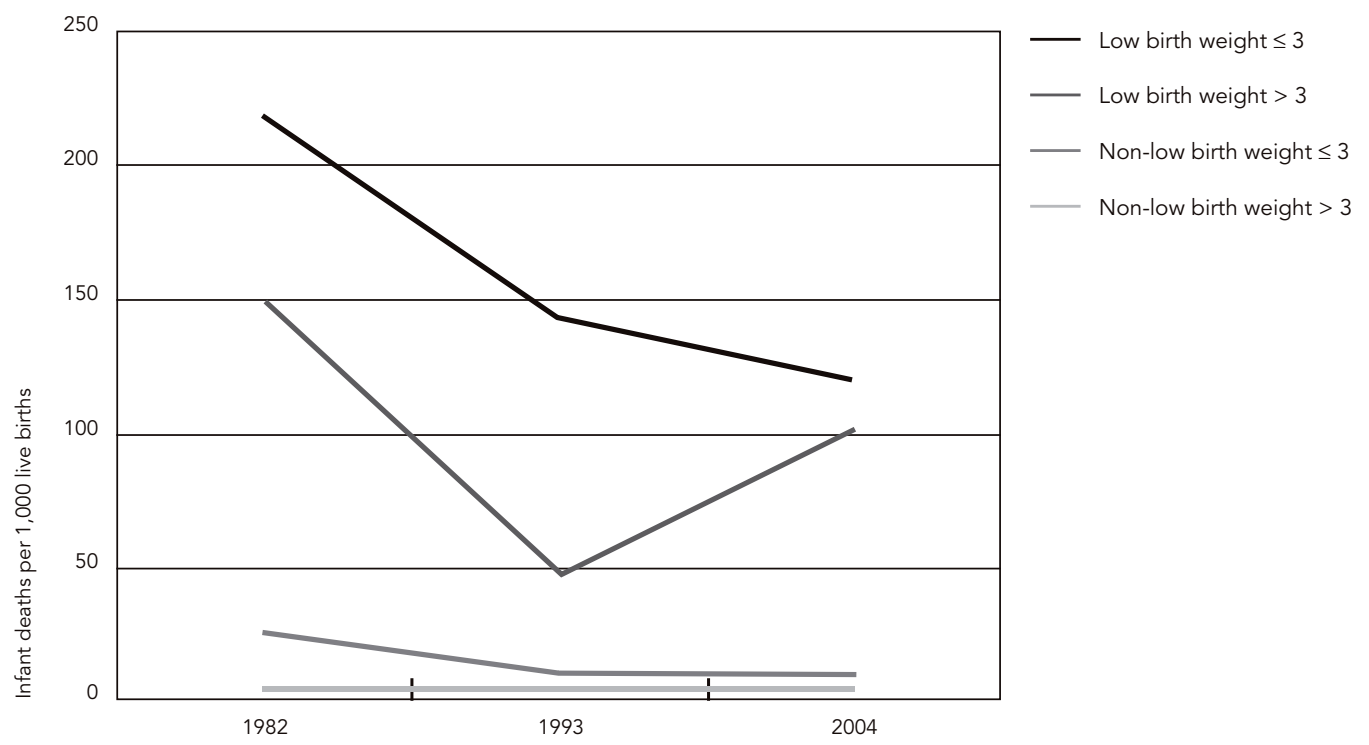

for the diagnosis of cause of death (which allows for errors in the classification of deaths according to cause).

Improvements in the quality of information systems, with growing coverage of death registration, have been observed throughout Brazil 1 . An important finding of the 2004 cohort was the absence of under-reporting of child deaths in Pelotas, continuing the trend that was already apparent in 1993 6. The apparent increase in the proportion of deaths due to ill-defined causes may have been due to a more rigorous approach adopted by the research team in 2004 in the classification of causes of death, as well as to the fact that, in 1993, necropsies were performed by a group of pathologists in cases where the cause of death was poorly-defined 14 .

In 2004, infant mortality rates among families with income greater than 6 MW were similar to those of countries with the lowest mortality rates in the world, such as Japan and Sweden -3.3 and 2.8 per 1,000 , respectively 15 . However, the infant mortality rate for the city as a whole (19.4 per 1,000), is still high, and is higher than those of neighboring Latin American countries such as Argentina and Uruguay 15. To achieve the World Health Organization's (WHO) Millennium Development Goal 16 of a two-thirds reduction in mortality between 1990 and 2015, Pelotas would have to reach a rate of 7 per 1,000 by 2015 , which shows that there is still much to be done.

The current scenario of infant health in Pelotas is worse than that of the State of Rio Grande do Sul as a whole, which, since the early 1980's, has been showing a progressive improvement in infant mortality rates, from 33.2 per 1,000 in 1982 to 15.1 in 2004 17. The 1990s witnessed the stabilization of the infant mortality rate in Pelotas in its two components (neonatal and post-neonatal). The post-neonatal rate -7.1 per 1,000 - is high compared to the State of Rio Grande do Sul as a whole, which registered 5.1 post-neonatal deaths per 1,000 live births in the same year. The contribution of post-neonatal mortality to infant mortality in Pelotas was $37 \%$, higher than the $33.6 \%$ contribution registered for the entire state 17 .

Worthy of note is the fact that, in the three cohorts, the risk of dying during the first year of life was always greater among the children of families with incomes of up to one MW, regardless of birth weight. As previously observed by other authors, risk of death is directly related to a population's socioeconomic conditions, indicating inequity in healthcare 18 .

The principle cause of infant mortality is still perinatal conditions, which account for $50 \%$ of all deaths. Next are respiratory infections and illdefined causes. This is in contrast to 1993, when 
the second position was occupied by congenital malformations. The substantial increase in infant mortality in the "respiratory infections" and "other infections" groups may reflect the quality of management, especially with respect to the availability of antibiotics for treatment. The reduction of deaths due to diarrhea, on the other hand, is likely to be related to improvements in basic sanitation. The current pattern in Pelotas reflects an intermediate scenario between locations with high and those with low infant mortality. In countries in which infant mortality is high, major causes of death in the first year of life are related primarily to malnutrition and infectious disease, and malformations account for $5 \%$ or less of these deaths 18. As other causes of death are controlled, malformations acquire a proportionally greater importance. The scenario in Pelotas is similar to that of Brazil as a whole, where congenital malformations are the second most important cause of infant mortality, accounting for $11.2 \%$ of deaths $19,20,21$.

Profound socioeconomic changes took place in the city between the last two cohorts. The shutting down of most of the region's preserved foods industries (Forum Pelotas online. http://www. forumpelotasonline.slg.br/index.php, accessed on $07 / \mathrm{Sep} / 2006$ ) has changed the profile of the city's economy, which is now based on agribusiness and commerce (Wikipedia. Pelotas. http:// pt.wikipedia.org/wiki/Pelotas\#Economia, accessed on 07/Sep/2006). There has been an overall impoverishment in the city; for instance, the ratio between the per capita GIPs of the city of Pelotas and the State of Rio Grande do Sul fell from 0.8 in the early 1990's to 0.5 in 20014 .

Although the economic crisis may in part account for the lack of progress in the last decade, other factors are also likely to have played a role, given that the majority of neonatal deaths tend to be associated with gestational conditions and antenatal and delivery care. Traditionally, concern was focused on the lack of care, which would allow potentially avoidable deaths to occur; more recently, however, there is reason to believe that excess medical interventions may be playing a negative role in the effort to reduce mortality.

The most striking finding of the 2004 cohort was the marked increase in the prevalence of preterm births, from $6.3 \%$ in 1982 to $11.4 \%$ in 1993 and $14.7 \%$ in 200422 . When stratified by family income, the data of the 2004 cohort show that, although the risk of death among poor children with low birth weight remained constant, there was an increase in risk among richer children, leading to a reduction in the gap between these two groups. Unfortunately, such a reduction was not due to an improvement in living conditions or healthcare among the poor, as would be desired, but instead was due to an increase in these rates among the rich. Part of this reduction was certainly due to the increase in the number of preterm births among the latter, the prevalence of which, in 2004, was similar to that of poor children 23. Preterm babies showed greater risk of dying than term babies, especially during the first week of life, and this risk increases as gestational age at birth decreases 24 . Other analyses of the 2004 cohort have shown that even mild preterms ( 34 to 36 weeks gestational age) show a fivefold greater risk of neonatal death than term babies 25 .

The reasons for such an increase range from the poor quality of antenatal care reported in other local studies 26 to the use of inappropriate technology for mother and newborn care 23,27. The presence of trained professionals during delivery is essential for reducing infant mortality due to neonatal causes related to asphyxia and infection. On the other hand, excessive medical intervention for deliveries is likely to have had a negative effect in Pelotas. Medical procedures such as c-sections, episiotomy, amniotomy, and the use of oxytocin without partogram, are known indicators of excessive medical intervention, which may lead to increased risks to the newborn 28 . The increasing rate of c-sections in Pelotas during this period - from $28 \%$ to $45 \%$ - is indicative of such risk.

Furthermore, miscalculation of gestational age may also lead to preterm delivery. Obstetric ultrasonography was virtually universal in Pelotas in 2004. However, the misinterpretation of ultrasonography results, as determined by the date of the mother's last period, even for exams carried out before the $20^{\text {th }}$ week of pregnancy, have led to a mean overestimation of gestational age of about two weeks 23 .

Although the improvements in living conditions (maternal schooling, nutrition, etc.) observed among pregnant women in Pelotas in 2004 may have led to a decrease in late neonatal mortality, this is less true for the early neonatal period. Separating the effects on infant mortality of contextual factors from those related to the quality of health care is a challenge. Poverty, for instance, affects both the context in which the child is born and the quality of care received at birth, and both variables play important roles in infant mortality. The relative weights of context and care, however, seem to differ in determining the risk of death at different times during the first year of life. Historically, developed countries only achieved a reduction in the number of deaths during the first week of life upon improving the 
quality of obstetric care and the availability of antibiotics 15 .

Encouraged by these results, local healthcare managers and the 2004 cohort research team began a process of in-depth investigation of the causes of neonatal mortality in the city. Differences between hospitals were identified 29 and analyzed in partnership with the heads of maternities and neonatal intensive care units. All the city's health professionals were invited to par- ticipate in a large-scale forum in which strategies for the prevention of infant mortality were discussed. There is currently a consensus among managers, researchers, and healthcare professionals that the reduction of infant mortality in Pelotas will require a large investment in the prevention of neonatal mortality, by means of guaranteeing universal access to appropriate delivery and newborn care.

\section{Resumo}

Os autores estudaram tendências temporais nas taxas de mortalidade infantil e fatores associados em três coortes em Pelotas, Rio Grande do Sul, Brasil, de 1982, 1993 e 2004. Todos os nascimentos hospitalares e óbitos foram identificados através de visitas regulares aos hospitais, cartórios e cemitérios. Esses dados foram utilizados para calcular as taxas de mortalidade neonatal, pós-neonatal e infantil por mil nascidos vivos. Também foram calculadas as taxas específicas de acordo com causa de óbito, sexo, peso ao nascer, idade gestacional e renda familiar. $\mathrm{O}$ coeficiente de mortalidade infantil diminuiu de 36,4 por mil nascidos vivos em 1982 para 21,1 em 1993 e 19,4 em 2004. As principais causas de mortalidade infantil em 2004 foram causas perinatais e infecções respiratórias. Entre 1993 e 2004, houve uma redução de $16 \%$ na mortalidade entre crianças de baixo peso ao nascer de famílias pobres; entretanto, esse mesmo coeficiente aumentou mais de $100 \%$ entre famílias de renda alta, devido ao aumento no número de partos prematuros nesse grupo. É provável que a estabilização da mortalidade infantil na última década seja devida à excessiva medicalização da gravidez e da atenção ao parto.

Mortalidade Infantil; Recém-Nascido de Baixo Peso; Nascimento Prematuro; Renda; Estudos de Coortes

\section{Contributors}

I. S. Santos designed the research question and wrote the first draft of the article. A. Matijasevich conducted the analyses. A. M. B. Menezes, D. M. Mota, E. P. Albernaz, A. J. D. Barros, A. Matijasevich, F. C. Barros and C. G. Victora contributed to the interpretation of the analyses and assisted with the editing of the article. 


\section{References}

1. Departamento de Análise e Situação em Saúde, Secretaria de Vigilância em Saúde, Ministério da Saúde. Saúde Brasil 2005: uma análise da situação de saúde no Brasil. Brasília: Ministério da Saúde; 2005. (Série C. Projetos, Programas e Relatórios).

2. Departamento de Análise e Situação em Saúde, Secretaria de Vigilância em Saúde, Ministério da Saúde. Saúde Brasil 2004: uma análise da situação de saúde. Brasília: Ministério da Saúde; 2004. (Série G. Estatística e Informação em Saúde).

3. Fundo das Nações Unidas para a Infância. Retrato estatístico dos direitos da criança e do adolescente. Brasília: Fundo das Nações Unidas para a Infância; 2006.

4. Barros AJD, Santos IS, Matijasevich A, Araújo CL, Gigante DP, Menezes AMB, et al. Methods used in the 1982, 1993, and 2004 birth cohort studies from Pelotas, Rio Grande do Sul State, Brazil, and a description of the socioeconomic conditions of participants' families. Cad Saúde Pública 2008; 24 Suppl 3:S371-80.

5. Victora CG, Barros FC, Vaughan JP. Epidemiologia da desigualdade: um estudo longitudinal de 6.000 crianças brasileiras. 2ạ Ed. São Paulo: Centro Brasileiro de Estudos de Saúde/Editora Hucitec; 1989.

6. Menezes AMB, Victora CG, Barros FC, Albernaz E, Menezes FS, Jannke HA, et al. Mortalidade infantil em duas coortes de base populacional no Sul do Brasil: tendências e diferenciais. Cad Saúde Pública 1996; 12 Suppl 1:S79-86.

7. Puffer RR, Serrano CV. Patterns of mortality in childhood: the inter-American investigation of mortality in childhood. Washington DC: Pan American Health Organization; 1973.

8. World Health Organization. International statistical classification of diseases and related health problems, ninth revision. Geneva: World Health Organization; 1982.

9. World Health Organization. International statistical classification of diseases and related health problems, tenth revision. Geneva: World Health Organization; 1993.

10. Lubchenco LO, Searls DT, Brazie JV. Neonatal mortality rate: relationship to birth weight and gestational age. J Pediatr 1972; 81:814-22.

11. Alexander GR, Himes JH, Kaufman RB, Mor J, Kogan M. A United States national reference for fetal growth. Obstet Gynecol 1996; 87:163-8.

12. Dubowitz LM, Dubowitz V, Golberg C. Clinical assessment of gestational age in the newborn infant. J Pediatr 1970; 77:1-10.

13. Williams RL, Creasy RK, Cunningham GC, Hawes WE, Norris FD, Tashiro M. Fetal growth and perinatal viability in California. Obstet Gynecol 1982; 59:624-32.

14. Menezes AM, Victora CG, Barros FC, Menezes FS, Jannke H, Albernaz E, et al. Populational study of investigation of perinatal and infant deaths: methodology, validity of diagnosis and under-registration. J Pediatr (Rio J) 1997; 73:383-7.

15. World Health Organization. World health report 2005. Geneva: World Health Organization; 2005.
16. United Nations. The millennium development goals: report 2005. New York: United Nations; 2005.

17. Núcleo de Informação em Saúde, Departamento de Ações em Saúde, Secretaria da Saúde do Rio Grande do Sul. Estatísticas de saúde: mortalidade 2004. Porto Alegre: Núcleo de Informação em Saúde, Departamento de Ações em Saúde, Secretaria da Saúde do Rio Grande do Sul; 2005.

18. World Health Organization. World health report 1998. Geneva: World Health Organization; 1998.

19. Victora CG, Barros FC. Infant mortality due to perinatal causes in Brazil: trends, regional patterns and possible interventions. São Paulo Med J 2001; 119:33-42.

20. Lansky S, França E, César CC, Monteiro Neto LC, Leal MC. Mortes perinatais e avaliação da assistência ao parto em maternidades do Sistema Único de Saúde em Belo Horizonte, Minas Gerais, Brasil, 1999. Cad Saúde Pública 2006; 22:117-30.

21. Lansky S, Evangelista P, Drummond E, Almeida MC, Ishitani L. Mortalidade infantil em Belo Horizonte: avanços e desafios. Rev Méd Minas Gerais 2006; 16:105-12.

22. Barros FC, Victora CG, Matijasevich A, Santos IS, Horta BL, Silveira MF, et al. Preterm births, low birth weight, and intrauterine growth restriction in three birth cohorts in Southern Brazil: 1982, 1993 and 2004. Cad Saúde Pública 2008; 24 Suppl 3:S390-8.

23. Barros FC, Victora CG, Barros AJ, Santos IS, Albernaz E, Matijasevich A, et al. The challenge of reducing neonatal mortality in middle-income countries: findings from three Brazilian birth cohorts in 1982, 1993, and 2004. Lancet 2005; 365:847-54.

24. Kramer MS. Determinants of low birth weight: methodological assessment and meta-analysis. Bull World Health Organ 1987; 65:663-737.

25. Santos IS, Matijasevich A, Silveira MF, Schowitz K, Barros AJ, Victora CG, et al. Associated factors and consequences of late preterm births: results from the 2004 Pelotas birth cohort. Paediatr Perinat Epidemiol 2008; 22:350-9.

26. Silveira DS, Santos IS, Dias-da-Costa JS. Atenção pré-natal na rede básica: uma avaliação da estrutura e do processo. Cad Saúde Pública 2001; 17:131-9.

27. Cesar JA, Matijasevich A, Santos IS, Barros AJD, Dias-da-Costa JS, Barros FC, et al. The use of maternal and child health services in three population-based cohorts in Southern Brazil, 1982-2004. Cad Saúde Pública 2008; 24 Suppl 3:S427-36.

28. Villar J, Valladares E, Wojdyla D, Zavaleta N, Carroli G, Velazco A, et al. Caesarean delivery rates and pregnancy outcomes: the $2005 \mathrm{WHO}$ global survey on maternal and perinatal health in Latin America. Lancet 2006; 367:1819-29.

29. Barros AJD, Matijasevich A, Santos IS, Albernaz EP, Victora CG. Neonatal mortality: description and effect of hospital of birth after risk adjustment. Rev Saúde Pública 2008; 42:1-9.

Submitted on 29/Mar/2007 Final version resubmitted on $07 /$ Nov/2007 Approved on 14/Jan/2008 